\title{
Does kisspeptin signaling have a role in the testes?
}

\author{
Hua Mei ${ }^{1}$, Joanne Doran ${ }^{2}$, Victoria Kyle ${ }^{3}$, Shel-Hwa Yeo ${ }^{3}$ and William H. Colledge ${ }^{3}$ \\ 1 Jules Stein Eye Institute, University of California, Los Angeles, CA, USA \\ ${ }^{2}$ Takeda Cambridge Ltd., Cambridge, UK \\ ${ }^{3}$ Department of Physiology, Development and Neuroscience, University of Cambridge, Cambridge, UK
}

\section{Edited by:}

Riccardo Pierantoni, Second

University of Naples, Italy

Reviewed by:

Rosanna Chianese, Second University of Naples, Italy

Rosaria Meccariello, University of

Naples Parthenope, Italy

*Correspondence:

William H. Colledge, Department of Physiology, Development and Neuroscience, University of Cambridge, Downing Street, Cambridge, CB2 3EG, UK

e-mail:whc23@cam.ac.uk
Kisspeptins are a family of overlapping neuropeptides encoded by the Kiss1 gene that regulate the mammalian reproductive axis by a central action in the hypothalamus to stimulate $\mathrm{GnRH}$ release. Kisspeptins and their receptor (GPR54 also called KISS1R) are also expressed in the testes but a functional role in this tissue has not been confirmed. We examined which cell types in the testes expressed kisspeptin and its receptor by staining for $\beta$-galactosidase activity using tissue from transgenic mice with LacZ targeted to either the Kiss 1 or the Gpr54 genes. Expression of both genes appeared to be restricted to haploid spermatids and this was confirmed by a temporal expression analysis, which showed expression appearing with the first wave of haploid spermatid cells at puberty. We could not detect any kisspeptin protein in spermatids however, suggesting that the Kiss 1 mRNA may be translationally repressed. We tested whether kisspeptin could act on Leydig cells by examining the effects of kisspeptin on the immortalized Leydig cell line MA10. Although MA-10 cells were shown to express Gpr54 by RT-PCR, they did not respond to kisspeptin stimulation. We also tested whether kisspeptin could stimulate testosterone release by a direct action on the testes using explants of seminiferous tubules. The explants did not show any response to kisspeptin. The functional integrity of the MA-10 cells and the seminiferous tubule explants was confirmed by showing appropriate responses to the $\mathrm{LH}$ analog, human chorionic gonadotropin. These data suggest that kisspeptin signaling does not have a significant role in testes function in the mouse.

Keywords: kisspeptins, Gpr54/Kiss1r, testes, Leydig cells, testosterone secretion, spermatids

\section{INTRODUCTION}

Kisspeptins, encoded by the Kiss 1 gene, are an overlapping family of neuropeptides required for activation and maintenance of the mammalian reproductive axis [for review, see Ref. (1)]. Kisspeptins are encoded as a 145 -amino-acid precursor protein in humans that is cleaved into shorter peptides (Kp54, Kp14, Kp13, and $\mathrm{Kp} 10$ ) that share a common RF-amide C-terminal decapeptide sequence. They all act as potent stimulators of GnRH release by signaling through the G-protein coupled receptor, GPR54 (also called KISS1R) expressed by GnRH neurons. Disruption of kisspeptin signaling causes hypogonadotropic hypogonadism in mice and humans (2-7). Mutant mice do not undergo sexual maturation at puberty and have low gonadotropic and sex steroid hormones levels caused by defective GnRH secretion from the hypothalamus. Conversely, activating mutations of GPR54 cause precocious puberty in humans (8).

In addition to the role of kisspeptins in the central regulation of the reproductive axis, Gpr54 expression has been detected in the testes of humans $(9,10)$, mice $(3)$, rats $(11)$, and frogs (12) raising the possibility that kisspeptins may also act at this location. Kisspeptins have been immunolocalized to Leydig cells in mice (13) and kisspeptin and GPR54 have been detected in human sperm, mainly localized to the head, neck, and the flagellum midpiece (14).

Although the expression profile of Kiss1 and Gpr54 suggests that kisspeptin signaling might have a role in the testes, very little has been done to test this hypothesis. The data to support a role for kisspeptin in the testes is largely circumstantial and based on discrepancies between the normally direct relationship of LH and testosterone levels. For example, in rats, chronic (13 days) subcutaneous administration of kisspeptin reduced testosterone secretion without a significant decrease in plasma LH (15). In Rhesus monkeys, continuous intravenous infusion of human kisspeptin over 4 days maintained plasma testosterone levels even after the LH stimulation levels had fallen (16). When circulating testosterone levels were expressed relative to $\mathrm{LH}$ levels, the $[\mathrm{T}]:[\mathrm{LH}]$ ratios were significantly higher in the morning in the high dose kisspeptin treatment group compared to the vehicle group. This led to the suggestion that kisspeptins might augment the LHinduced secretion of testosterone. Support for this has come from kisspeptin administration in Rhesus monkeys pre-treated with acyline, a GnRH receptor antagonist, to allow the intratesticular actions of kisspeptin to be evaluated without the confounding effects of LH release from the pituitary (17). Kisspeptin administration significantly increased human chorionic gonadotropin (hCG)-stimulated testosterone levels in acycline treated monkeys compared to hCG treatment alone (17) suggesting that kisspeptin might enhance LH responses in Leydig cells.

To further investigate the possible function(s) of kisspeptin in the mouse testes, we used transgenic mice with Kiss1 and Gpr54 alleles targeted with a $L a c Z$ reporter gene to define the testicular cell expression profile of these genes. We also tested whether 
kisspeptins can stimulate testosterone release from an immortalized mouse Leydig cell line and from primary testes explants in culture.

\section{MATERIALS AND METHODS MOUSE LINES AND MAINTENANCE}

The 129S6/SvEv mutant mice with a targeted disruption of the Gpr54 or Kiss1 genes were generated as described previously (2, 5). All mice were maintained on a 12:12-h light-dark cycle (light on between 6:30 a.m. and 6:30 p.m.) with ad libitum access to food and water. Experimental procedures were performed under authority of a Home Office Project License and approved by a Local Ethics Committee.

\section{MA-10 CELL CULTURE}

The mouse Leydig tumor cell line MA-10 (18) was a generous gift from Dr. Mario Ascoli (University of Iowa, Iowa City, IA, USA). The MA-10 cells were maintained in RPMI-1640 medium (Sigma-Aldrich, Dorset, UK) containing 10\% horse serum (Sigma-Aldrich, Dorset, UK) and 10\% newborn calf serum (Sigma-Aldrich, Dorset, UK), and the cells were grown at $37^{\circ} \mathrm{C}$ in an humidified atmosphere of $5 \% \mathrm{CO}_{2}$. The growth medium was refreshed every 2 days to provide sufficient nutrition for cell growth.

\section{RT-PCR GENE EXPRESSION ANALYSIS OF MA-10 CELLS}

Total RNA was isolated from MA-10 cells using a NucleoSpin ${ }^{\circledR}$ RNA II kit (Cat No: 740955, MACHEREY-NAGEL GmbH \& Co. KG) following the manufacturer's protocol. The time of the on-column DNA digestion was extended from 15 to $45 \mathrm{~min}$ to ensure complete removal of genomic DNA. The RNA was reverse transcribed into cDNA using SuperScript III Reverse Transcriptase (Cat No: 18080-044, Invitrogen, UK) following the protocol provided by the manufacturer. Standard PCR was performed as follows: the samples were denatured for $5 \mathrm{~min}$ at $95^{\circ} \mathrm{C}$ and amplified for 44 cycles $\left(30 \mathrm{~s}\right.$ at $93^{\circ} \mathrm{C}, 1 \mathrm{~min}$ at $60^{\circ} \mathrm{C}$, and $2 \mathrm{~min}$ at $70^{\circ} \mathrm{C}$ ). The primer sequences were: Kiss 1 (Forward: tgctgcttctcctctgtgtcg; Reverse: gccgaaggagttccagttgta, 310 bp product), Gpr54 (Forward: gccttcgcgctctacaacctgctg; Reverse: aaggcatagagcagcggattgagc, 367 bp product), GnRH (Forward: cggcattctactgctgactgt; Reverse: catcttcttctgctggcttc, 229 bp product), $\beta$-actin (Forward: ctgtattccctccatcgtg; Reverse: gggtcaggatacctctcttgc, 113 bp product). RNA without a reverse transcription step was used as a negative control for identification of genomic DNA contamination and cDNA from wild-type hypothalamus was used as a positive control for Kiss 1 amplification.

\section{X-GAL STAINING OF TESTES SECTIONS}

Testes were fixed in $1 \%$ paraformaldehyde/PBS overnight at $4^{\circ} \mathrm{C}$, cryoprotected with $30 \%$ sucrose/PBS overnight at $4^{\circ} \mathrm{C}$, and cryosectioned at $20 \mu \mathrm{m}$ onto poly-lysine coated slides. Sections were air dried at room temperature, rehydrated in PBS and $\beta$ galactosidase activity detected using a LacZ staining solution [ $1 \mathrm{mM} \mathrm{MgCl} 2,1 \mathrm{mg} / \mathrm{ml} \mathrm{X-gal} \mathrm{(5-bromo-4-chloro-3-indolyl} \beta$-Dgalactopyranoside), $5 \mathrm{mM}$ potassium ferricyanide, $5 \mathrm{mM}$ potassium ferrocyanide in $\mathrm{PBS}$ ] at $37^{\circ} \mathrm{C}$ overnight, and counterstained with $1 \%$ Saffronin.

\section{IMMUNOHISTOCHEMISTRY TO DETECT KISSPEPTIN EXPRESSION}

Testes were fixed in 4\% paraformaldehyde/Tris-buffered saline (TBS) for $5 \mathrm{~h}$ at room temperature and transferred to $30 \%$ sucrose/TBS overnight at $4^{\circ} \mathrm{C}$. The testes were then cryosectioned at $15 \mu \mathrm{M}$, air dried at room temperature, rehydrated in TBS, and slide-mounted immunohistochemistry was performed to detect kisspeptin expression. Polyclonal antibody AC566 raised in rabbits against mouse Kp10 was a generous gift from Alain Caraty, Tours, France. Characterization and specificity of AC566 has been described previously $(5,19-21)$.

Sections were treated with 3\% hydrogen peroxide for $15 \mathrm{~min}$ to quench endogenous peroxidase and then washed in TBS. To visualize kisspeptin expression, sections were incubated with the antibody at 1:2000 dilution for $8 \mathrm{~h}$ at room temperature. For secondary antibody labeling, sections were incubated with biotinylated goat anti-rabbit (1:100; Cat No: BA-1000, Vector Laboratories, Peterborough, UK) immunoglobulins at room temperature followed by incubation with Vector avidin-peroxidase (1:50; Cat No: PK4000, Vector Laboratories, Peterborough, UK). Finally, the sections were rinsed and immunoreactivity was revealed with glucoseoxidase and nickel-enhanced diaminobenzidine hydrochloride $(12.5 \mathrm{mg} / \mathrm{ml})$. Sections were counterstain with hematoxylin, dehydrated in ethanol followed by Histoclear, and then coverslipped with DPX.

\section{PROGESTERONE RELEASE EXPERIMENTS FROM MA-10 CELLS}

The MA- 10 cells were seeded at $2.5 \times 10^{5}$ cells/well ( 24 -well plates) $24 \mathrm{~h}$ before the hormone treatment. The cells were treated with increasing concentrations of Kp10 (human Metastin 45-54) (1, 10 , or $20 \mu \mathrm{M}$ ) (Cat No: M2816, Sigma-Aldrich, Dorset, UK) or $\mathrm{Kp} 10$ followed by hCG $(0.012 \mathrm{IU} / \mathrm{ml}$ as the final concentration) (Cat No: CG5, Sigma, Saint Louis, MO, USA). PBS was added as a negative control. Each condition was tested in triplicate. After $4 \mathrm{~h}$, the media was collected for progesterone measurement. After collection of media, the MA-10 cells were rinsed twice with PBS and lysed in $1 \times$ lysis buffer (reporter lysis buffer, Cat No: E397A, Promega, UK) by a freeze-thaw cycle. The lysate was briefly centrifuged and the protein content of the supernatant determined with a Bio-Rad Bradford Assay following the standard protocol.

\section{PRIMARY CULTURE OF TESTES EXPLANTS}

The testes from adult wild-type mice were cut into two pieces (approximately $40 \mathrm{mg} /$ piece) without removing the tunica and each piece was cut and flattened to a 1-mm thickness on a Nylon membrane (Cat No: 1417240, Boehringer-Mannheim, Indianapolis, IN, USA) floating in phenol red-free DMEM medium (Cat No: 21063, GIBCO) (300 $\mu \mathrm{l} /$ well for 12-well plate) supplemented with $1 \times$ penicillin/streptomycin. The tissues were immediately treated with vehicle, Kp10 $(1 \mu \mathrm{M})$, hCG $(0.6 \mathrm{IU} / \mathrm{ml})$, or a mixture of Kp10 $(1 \mu \mathrm{M})$ and hCG $(0.6 \mathrm{IU} / \mathrm{ml})$, respectively. Each condition was tested in at least four repeat wells. The tissues were cultured at $37^{\circ} \mathrm{C}$ in an atmosphere of $5 \% \mathrm{CO}_{2}$ and the media collected at different time points. Fresh media was added at each time point after media collection.

\section{HORMONE ASSAYS}

Testosterone and progesterone were measured using ELISA kits (Cat No: EIA1559 and EIA1561 from DRG International, USA) 
according to the manufacturer's instructions. The testosterone ELISA kit had a sensitivity of $0.083 \mathrm{ng} / \mathrm{ml}$, an inter-assay variation of $6.7 \%$, and an intra-assay variation of $3.3 \%$. The progesterone ELISA kit had a sensitivity of $0.045 \mathrm{ng} / \mathrm{ml}$, intra-assay variation of $7 \%$, and inter-assay variation of $5 \%$.

\section{RESULTS}

\section{Gpr54 AND KISS1 ARE EXPRESSED IN THE MOUSE TESTES}

The Gpr54 and Kiss1 alleles in the transgenic mice have been tagged with a $L a c Z$ gene that allows their gene expression patterns to be visualized by staining for $\beta$-galactosidase activity. Staining was observed within seminiferous tubules from both Kiss $1^{+/-}$ (Figure 1A) and Gpr54 ${ }^{+/-}$mice (data not shown) but not in wildtype mice (Figure 1A). Background staining was observed in the epididymis and the vas deferens of wild-type mice as the epithelial cells in these tissues express an endogenous galactosidase-like enzymatic activity. To define the cells in which Kiss 1 and Gpr54 are expressed, cryosection of testes were stained for $\beta$-galactosidase activity. The staining in cryosections was localized to the region of the seminiferous tubules that contained round spermatids (arrowed in Figures 1B,C). The spermatids are easily recognized as they have smaller nuclei than spermatocytes and are four-times more abundant as they have just completed meiosis. Very faint $\beta$-galactosidase staining was also found in the Leydig cells in the Gpr54 $4^{+/-}$mice (Figure 1D) but not in the Kiss ${ }^{+/-}$mice (data not shown).

To confirm that the $\beta$-galactosidase expression was localized to spermatid cells, the time point at which expression was first observed during the first spermatogenic cycle was determined. Expression of Kiss1 and Gpr54 could not be observed prior to 3 weeks of age but staining was seen from 1 month of age which corresponds to the time at which the spermatids first appear in mice (Figure 2).

Kisspeptin protein expression in the mouse testes was visualized using a well characterized rabbit antiserum highly specific for mouse Kp10 (20). Strong immunoreactivity was found in Leydig cells with no staining in spermatids (Figure 1E). As a control for antibody specificity, testes sections from Kiss1 mutant mice lacking kisspeptin protein were used and no immunoreactivity was observed (Figure 1E). This Leydig staining may be non-specific however, as no kisspeptin protein was detected in Gpr54 mutant mice (data not shown).

\section{Kp10 DOES NOT STIMULATE STEROIDOGENESIS IN THE LEYDIG CELL LINE, MA-10}

To test whether Kp10 could stimulate testosterone release, the mouse Leydig cell line, MA-10, was used $(18,22)$. MA-10 cells, like normal Leydig cells, express $\mathrm{LH}$ receptors and respond to hCG stimulation. MA-10 cells have low expression and activity of $\mathrm{P} 450 \mathrm{c} 17$ that is the enzyme that converts progesterone into 17$\mathrm{OH}$ progesterone and finally into testosterone, thus MA-10 cells produce progesterone as the principle steroid hormone instead of testosterone $(18,22)$.

The MA-10 cells were examined for expression of Kiss 1 and Gpr54 to determine whether they might be capable of responding to kisspeptins. There was a PCR product for Gpr54 (Figure 3A), indicating that MA-10 cells endogenously express this gene but

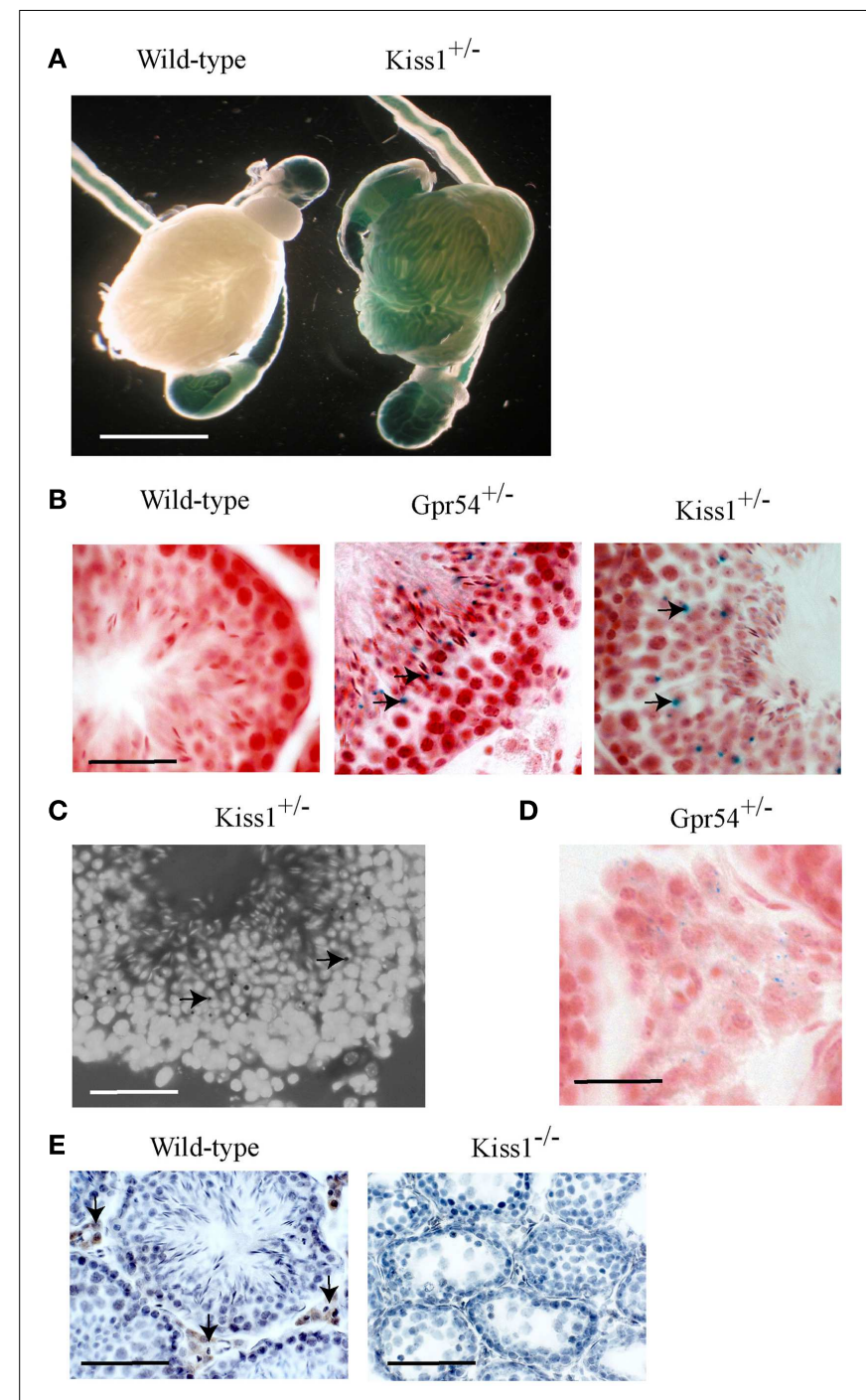

FIGURE 1 | Kiss1 and Gpr54 expression in the mouse testes (A) Expression of Kiss 1 in seminiferous tubules of the testes visualized by $X$-gal staining (blue) for $\beta$-galactosidase activity. Note the non-specific staining in the epididymis and vas deferens of the wild-type testes. Scale bar $=5 \mathrm{~mm}$. (B) Cryosections of testes from adult wild-type, Gpr54 ${ }^{+/-}$, and Kiss $1^{+/-}$mice showing expression (arrowed) localized to spermatid cells of seminiferous tubules. Sections were stained for $\beta$-galactosidase activity (blue) and counterstained with Saffronin (red). Scale bar $=100 \mu \mathrm{m}$. (C) Testes cryosection from Kiss $1^{+/-}$mice stained for $\beta$-galactosidase activity (black dots, arrowed) and counterstained with DAPI to visualize cell nuclei illustrating clearer expression in spermatid cells. Scale bar $=100 \mu \mathrm{m}$. (D) Low expression of Gpr54 in Leydig cells visualized by X-gal staining. Scale bar $=50 \mu \mathrm{m}$. (E) Kisspeptin immunoreactivity localized to Leydig cell in wild-type mice (arrowed) but not Kiss 1 mutant mice. Scale bar $=200 \mu \mathrm{m}$.

there was no detectable Kiss1 expression in the MA-10 cells. The MA-10 cell also expressed GnRH and $\beta$-actin transcripts (Figure 3A). No products were observed when non-transcribed RNA was used as the template, indicating that the RNA was free of genomic DNA contamination. A Kiss1 product was observed when hypothalamic cDNA was used from wild-type mice as a positive control. 


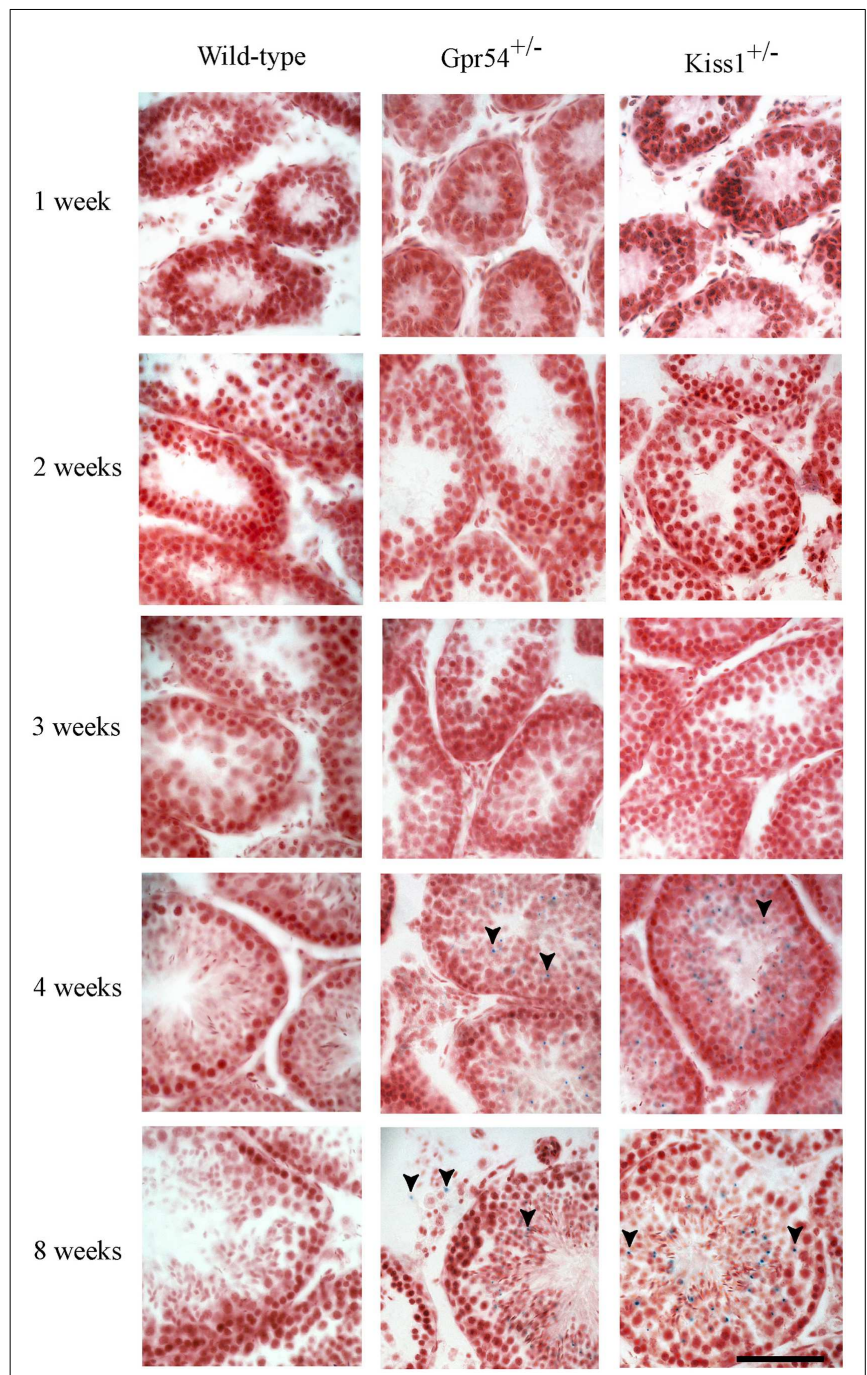

FIGURE 2 | Developmental time course of Gpr54 and Kiss1 expression in the mouse testes. Testes of wild-type (WT), Kiss $1^{+/-}$and Gpr54 ${ }^{+/-}$mice at different ages were cryosectioned, stained for $\beta$-galactosidase activity, and counterstained with Saffronin. Blue dots (arrowed) indicate expression of the Kiss 1 and Gpr54 genes. All photographs are at the same magnification. Scale bar $=50 \mu \mathrm{m}$.

As the MA-10 cells expressed the kisspeptin receptor, they were tested to see whether Kp10 could stimulate progesterone release. The cells were divided into two experimental groups. The first group was treated with increasing concentrations of human Kp10 followed by PBS, and the second group was treated with Kp10 followed by hCG to examine possible synergistic effects. After $4 \mathrm{~h}$, the media was assayed for progesterone, which was normalized to the protein content of the cell lysate to correct for variations in cell number. No significant difference in progesterone release was found between the vehicle (PBS) treatment and any of the three concentrations of Kp10 (Figure 3B), indicating that Kp10 cannot enhance progesterone release from the Leydig cell line even at a high concentration $(20 \mu \mathrm{M})$. There was also no significant difference in progesterone release between the cells treated with hCG

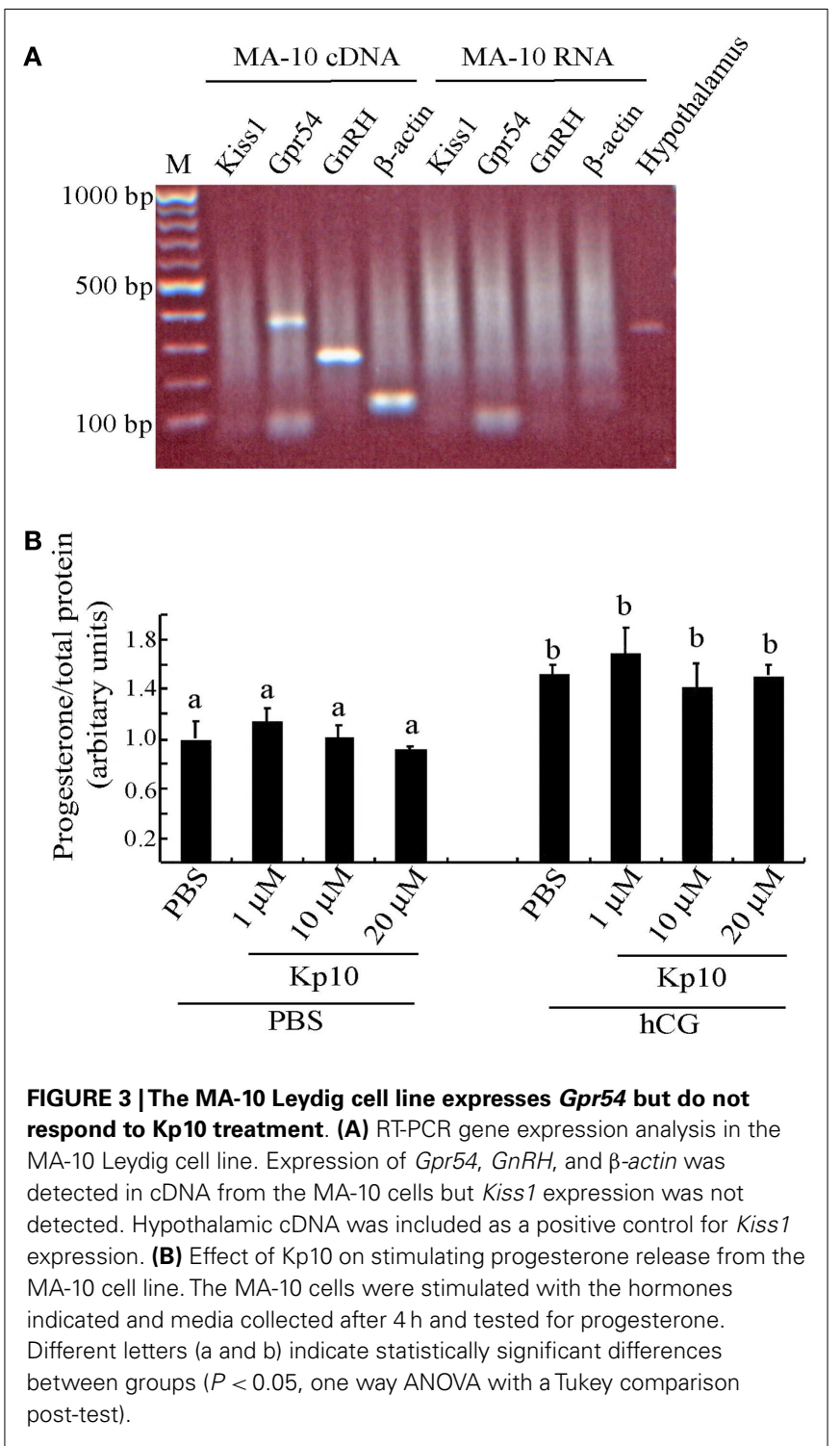

alone or those treated with hCG and Kp10 (Figure 3B), which suggests that Kp10 has no synergistic effect on progesterone release from MA-10 cells activated by hCG. However, there was a significant difference $(P<0.05)$ in progesterone release between the cells treated with PBS and those treated with hCG (Figure 3B), which indicates the functional responsiveness of the cells to hormonal stimulation.

\section{Kp10 DOES NOT STIMULATE TESTOSTERONE RELEASE FROM TESTES TISSUE CULTURE EXPLANTS}

To examine the possible action of Kp10 in a more physiological system, we tested whether Kp10 could stimulate testosterone release from primary explants of mouse testes. Pieces of adult wildtype mouse testes of similar weight (approximately $40 \mathrm{mg} /$ piece) were treated with vehicle (PBS), Kp10 $(1 \mu \mathrm{M})$, hCG $(0.6 \mathrm{IU} / \mathrm{ml})$, or a mixture of Kp10/hCG. Each condition was repeated with at least four samples. The media was collected at different time intervals for testosterone measurements. During the 0- to 4-h 
time period, the testosterone released after hCG treatment was significantly higher than that with the vehicle (PBS) treatment (Figure 4A), indicating that the cultured testes maintained the ability to respond to hormone stimulation. However, there was no obvious stimulation of testosterone release after Kp10 treatment. Also, the testosterone released in the PBS and hCG groups was not significantly different at incubation times $>4$ h due to increased unstimulated testosterone release (Figure 4A). Therefore, a 4-h incubation time was used to test whether there was any synergy between Kp10 and hCG in stimulating testosterone release (Figure 4B). Once again, testosterone release after hCG treatment was significantly higher than after PBS treatment (Figure 4B). No difference in testosterone release was detected between the testes fragments cultured in PBS or Kp10. There was also no difference in testosterone release between testes treated with hCG only and testes treated with hCG and Kp10 together. These data indicate that Kp10 has no effect on testosterone release from adult mouse testes and it has no synergistic action on testosterone release stimulated by hCG.

\section{DISCUSSION}

Kisspeptin neuropeptides are important central regulators of the mammalian reproductive axis with kisspeptin neurons acting upstream of GnRH neurons to stimulate GnRH release. In addition to this central role however, the expression profiles of Kiss1 and Gpr54 suggest that they may also have a function in peripheral tissues including the testes. We have shown using expression of a gene targeted $L a c Z$ reporter gene, that Kiss 1 and Gpr54 are expressed by round spermatid cells in the mouse testes. Expression profiling during postnatal gonadal maturation confirmed this as the expression only started to emerge after 1 month of age, which is the time when the spermatids first appear. As both Kiss 1 and Gpr54 were found to be expressed in spermatids, this raises the possibility that autocrine or paracrine kisspeptin signaling might be involved in spermiogenesis.

Round spermatid cells have just completed meiosis and will subsequently undergo the structural changes required to produce spermatozoa. During this structural remodeling, most of the cytoplasm is removed from the spermatids by the Sertoli cells, which will result in loss of $\beta$-galactosidase activity, which might explain why we do not observe staining in elongating spermatids and spermatozoa. Similarly, this cytoplasmic removal would remove any kisspeptin protein but GPR54 should be retained by virtue of its location in the plasma membrane. Indeed, GPR54 has been detected in the head region of human sperm and addition of kisspeptin can produce a modest rise in $\left[\mathrm{Ca}^{2+}\right]_{i}$ and sperm motility (14).

The functional significance of Kiss1 and Gpr54 expression in spermatids and sperm is still not clear however. The infertility of the Kiss 1 and Gpr54 mutant mice prevents performing functional tests with mutant sperm. It might be possible to initiate spermatogenesis in the mutant mice with pulsatile FSH and subcutaneous testosterone delivery. Although we have shown that Kiss 1 and Gpr54 mutant mice can initiate a low level of spermatogenesis when given a chow diet containing phytoestrogens (23), the number of sperm that can be isolated from the vas deferens and epididymis is too small for functional studies. It is noteworthy,

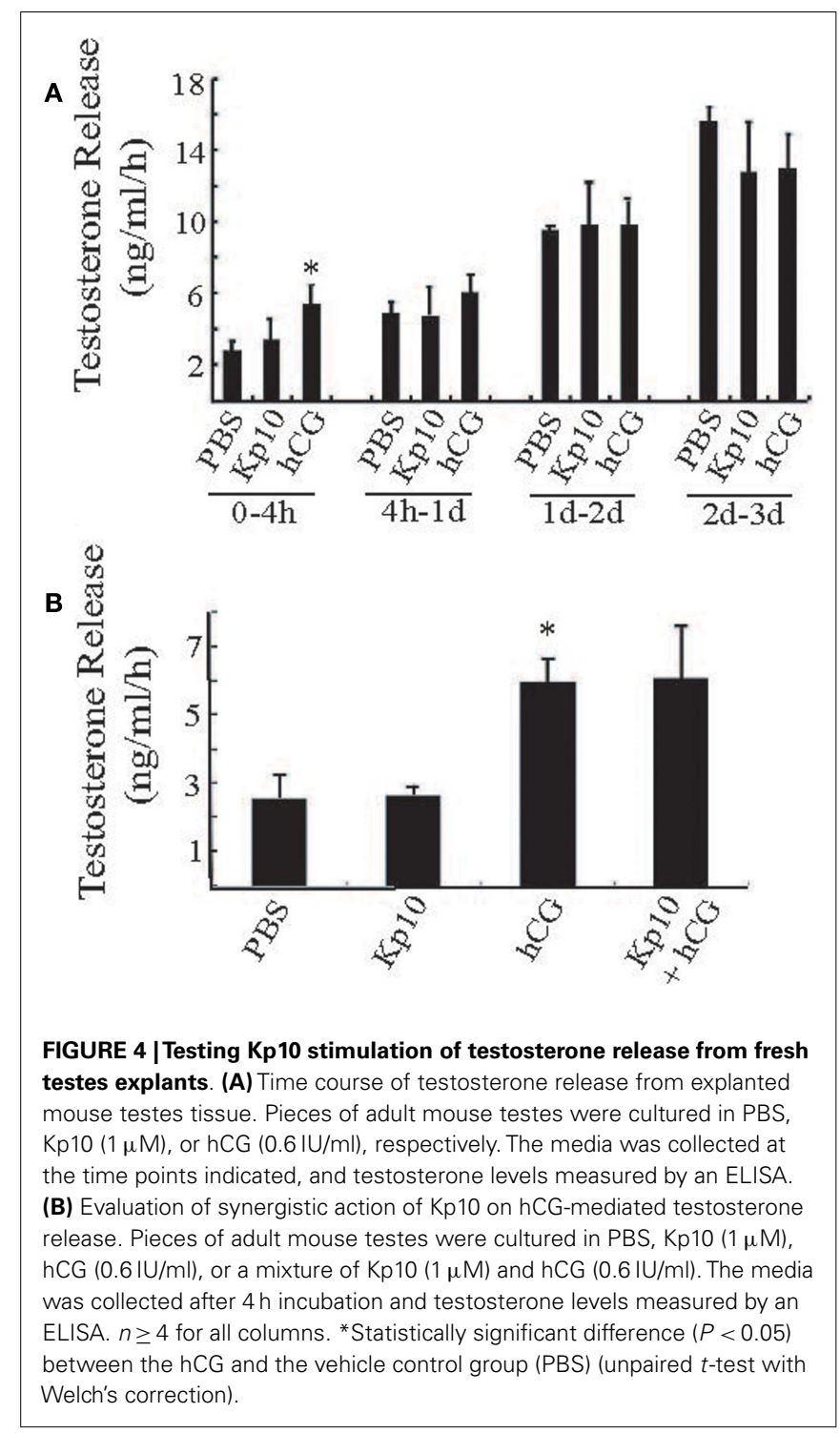

however, that several male patients with mutations in GPR54 and hypogonadotropic hypogonadism have responded to exogenous hormone treatment and achieved fertility [for review, see Ref. (24)] suggesting that in humans, GPR54 function is not essential for sperm function.

There is an important caveat to this expression data however. Although the LacZ expression indicates that the Kiss1 promoter is transcriptionally active in round spermatid cells, we could not detect kisspeptin immunoreactivity using a validated antibody capable of visualizing kisspeptin in the hypothalamus of mice (25). It is possible that the expression level of the kisspeptin protein is below the limits of detection and that X-gal staining for $\beta$ galactosidase activity is more sensitive. Alternatively, it is possible that Kiss1 transcripts are not translated into protein in spermatid cells. Several gene transcripts encoding proteins required for late spermiogenesis are expressed in round spermatids and translationally repressed until the elongating spermatid stage (26). Translationally repressed mRNAs have unusually long poly(A) tails 
of approximately $180 \mathrm{nt}$ and translation is associated with shortening of these tails (27). The presence of long poly(A) tails on Kiss 1 transcripts, which are not subsequently shortened, might provide a mechanism for the proposed translational repression in spermatids.

We detected kisspeptin immunoreactivity in Leydig cells of wild-type mice similar to that reported by Anjum and colleagues (13). The specificity of this immunoreactivity was suggested by absence of staining in Kiss 1 mutant mice, which do not produce any kisspeptin protein (5). This notwithstanding, we believe that the kisspeptin immunoreactivity found in the Leydig cells may not be authentic for the following reasons. Firstly, we did not detect Kiss 1 promoter activity in Leydig cell by $\beta$-galactosidase staining in Kiss $1^{+/-}$mice. Secondly, we did not detect Kiss 1 transcripts by RT-PCR in the immortalized Leydig cell line MA-10 although this may be a consequence of the cell immortalization process and the tendency for Kiss 1 expression to be suppressed during cell transformation and tumorigenesis. Finally, we failed to detect kisspeptin immunoreactivity in the Leydig cells of Gpr54 mutant mice, which can produce kisspeptin protein. We believe that the staining pattern observed in the Leydig cells of the wild-type mice is an artifact perhaps associated the high levels of steroidogenesis in these cells, which does not occur in Kiss1 or Gpr54 mutant mice.

We also observed a very low level of $\beta$-galactosidase staining in Leydig cells from Gpr54 $4^{+/-}$mice suggesting that these cells might express GPR54 protein. This was consistent with our detection of Gpr54 transcripts in the immortalized mouse Leydig cell line MA-10. Unfortunately, there are no anti-GPR54 antibodies with sufficient specificity to confirm expression of the endogenous GPR54 protein in the Leydig cells.

If there was co-expression of GPR54 and kisspeptin in Leydig cells, this would allow local autocrine or paracrine action within the testes. Previously published work has suggested that kisspeptins are able to enhance testosterone release after LH stimulation (17). We therefore examined whether Kp10 was able to stimulate testosterone release from the MA-10 cell line as well as testes fragments in culture. We found no evidence that Kp10 could directly stimulate testosterone release or enhance the actions of LH. This is in contrast to the recent data that kisspeptin administration significantly increased hCG-stimulated testosterone levels in acyline treated Rhesus monkeys compared to the responses with hCG treatment alone (17). As the acyline inhibits endogenous LH secretion from the pituitary, these responses suggest a direct, synergistic action of kisspeptin on the testes. The reason for the difference from our data is not known, but apart from a species difference, it might be that the enhancement by kisspeptin requires a sub-threshold level of LH stimulation and the concentration of hCG that we used was too high. It would be informative to test Kp10 responses to a lower range of hCG treatments in the testes explants. It is noteworthy, however, that Huma and colleagues have found that an intravenous injection of the kisspeptin antagonist p234 does not alter plasma testosterone levels in adult Rhesus macaques (28) suggesting that any action of kisspeptin on the testes is small. This conclusion is consistent with the observation that fertility can be restored in Gpr54 mutant mice by expression of a Gpr54 transgene in GnRH neurons (29) indicating that
GPR54 expression in the testes is also not essential for fertility in mice.

In summary, we have shown that the Kiss 1 and Gpr54 are both expressed in round spermatid cells of the mouse testes and Gpr54 is expressed by Leydig cells but we have not found any supporting data that kisspeptin signaling in the testes has a major role in spermatogenesis or testosterone secretion in the mouse.

\section{ACKNOWLEDGMENTS}

We thank Alain Caraty for providing us with the anti-kisspeptin antibody and Prof. Mario Ascoli for the MA-10 cells. We also thank the staff of the biofacility unit for excellent husbandry and Cara Walters for expert technical assistance. This work was supported by a BBSRC grant (BB/FO1936X/1).

\section{REFERENCES}

1. Oakley AE, Clifton DK, Steiner RA. Kisspeptin signaling in the brain. Endocr Rev (2009) 30:713-43. doi:10.1210/er.2009-0005

2. Seminara SB, Messager S, Chatzidaki EE, Thresher RR, Acierno JS Jr, Shagoury JK, et al. The GPR54 gene as a regulator of puberty. N Engl J Med (2003) 349:1614-27. doi:10.1056/NEJMoa035322

3. Funes S, Hedrick JA, Vassileva G, Markowitz L, Abbondanzo S, Golovko A, et al. The KiSS-1 receptor GPR54 is essential for the development of the murine reproductive system. Biochem Biophys Res Commun (2003) 312:1357-63. doi: 10.1016/j.bbrc.2003.11.066

4. Lapatto R, Pallais JC, Zhang D, Chan YM, Mahan A, Cerrato F, et al. Kiss1/mice exhibit more variable hypogonadism than gpr54/mice. Endocrinology (2007) 148:4927-36. doi:10.1210/en.2007-0078

5. d'Anglemont de Tassigny X, Fagg LA, Dixon JP, Day K, Leitch HG, Hendrick AG, et al. Hypogonadotropic hypogonadism in mice lacking a functional Kiss 1 gene. Proc Natl Acad Sci U S A (2007) 104:10714-9. doi:10.1073/pnas.0704114104

6. Dungan HM, Gottsch ML, Zeng H, Gragerov A, Bergmann JE, Vassilatis DK, et al. The role of kisspeptin-GPR54 signaling in the tonic regulation and surge release of gonadotropin-releasing hormone/luteinizing hormone. J Neurosci (2007) 27:12088-95. doi:10.1523/JNEUROSCI.2748-07.2007

7. Topaloglu AK, Tello JA, Kotan LD, Ozbek MN, Yilmaz MB, Erdogan S, et al. Inactivating KISS1 mutation and hypogonadotropic hypogonadism. N Engl J Med (2012) 366:629-35. doi:10.1056/NEJMoa1111184

8. Teles MG, Bianco SD, Brito VN, Trarbach EB, Kuohung W, Xu S, et al. A GPR54activating mutation in a patient with central precocious puberty. $N$ Engl J Med (2008) 358:709-15. doi:10.1056/NEJMoa073443

9. Kotani M, Detheux M, Vandenbogaerde A, Communi D, Vanderwinden JM, Le Poul E, et al. The metastasis suppressor gene KiSS-1 encodes kisspeptins, the natural ligands of the orphan G protein-coupled receptor GPR54. J Biol Chem (2001) 276:34631-6. doi:10.1074/jbc.M104847200

10. Ohtaki T, Shintani Y, Honda S, Matsumoto H, Hori A, Kanehashi K, et al. Metastasis suppressor gene KiSS-1 encodes peptide ligand of a G-protein-coupled receptor. Nature (2001) 411:613-7. doi:10.1038/35079135

11. Terao Y, Kumano S, Takatsu Y, Hattori M, Nishimura A, Ohtaki T, et al. Expression of KiSS-1, a metastasis suppressor gene, in trophoblast giant cells of the rat placenta. Biochim Biophys Acta (2004) 1678:102-10. doi:10.1016/j.bbaexp.2004. 02.005

12. Chianese R, Ciaramella V, Fasano S, Pierantoni R, Meccariello R. Kisspeptin receptor, GPR54, as a candidate for the regulation of testicular activity in the frog Rana esculenta. Biol Reprod (2013) 88:73. doi:10.1095/biolreprod.112.103515

13. Anjum S, Krishna A, Sridaran R, Tsutsui K. Localization of gonadotropinreleasing hormone $(\mathrm{GnRH})$, gonadotropin-inhibitory hormone $(\mathrm{GnIH})$, kisspeptin and GnRH receptor and their possible roles in testicular activities from birth to senescence in mice. J Exp Zool A Ecol Genet Physiol (2012) 317:630-44. doi:10.1002/jez.1765

14. Pinto FM, Cejudo-Roman A, Ravina CG, Fernandez-Sanchez M, Martin-Lozano D, Illanes M, et al. Characterization of the kisspeptin system in human spermatozoa. Int J Androl (2012) 35:63-73. doi:10.1111/j.1365-2605.2011.01177.x

15. Thompson EL, Murphy KG, Patterson M, Bewick GA, Stamp GW, Curtis AE, et al. Chronic subcutaneous administration of kisspeptin-54 causes 
testicular degeneration in adult male rats. Am J Physiol Endocrinol Metab (2006) 291:E1074-82. doi:10.1152/ajpendo.00040.2006

16. Ramaswamy S, Seminara SB, Pohl CR, DiPietro MJ, Crowley WF Jr, Plant TM. Effect of continuous intravenous administration of human metastin 4554 on the neuroendocrine activity of the hypothalamic-pituitary-testicular axis in the adult male rhesus monkey (Macaca mulatta). Endocrinology (2007) 148:3364-70. doi:10.1210/en.2007-0207

17. Irfan S, Ehmcke J, Wahab F, Shahab M, Schlatt S. Intratesticular action of kisspeptin in rhesus monkey (Macaca mulatta). Andrologia (2013). doi:10.1111/ and.12121

18. Ascoli M. Characterization of several clonal lines of cultured Leydig tumor cells: gonadotropin receptors and steroidogenic responses. Endocrinology (1981) 108:88-95. doi:10.1210/endo-108-1-88

19. Desroziers E, Mikkelsen J, Simonneaux V, Keller M, Tillet Y, Caraty A, et al. Mapping of kisspeptin fibres in the brain of the pro-oestrous rat. J Neuroendocrinol (2010) 22:1101-12. doi:10.1111/j.1365-2826.2010.02053.x

20. Franceschini I, Lomet D, Cateau M, Delsol G, Tillet Y, Caraty A. Kisspeptin immunoreactive cells of the ovine preoptic area and arcuate nucleus co-express estrogen receptor alpha. Neurosci Lett (2006) 401:225-30. doi:10.1016/j.neulet. 2006.03.039

21. Clarkson J, d'Anglemont de Tassigny X, Colledge WH, Caraty A, Herbison AE. Distribution of kisspeptin neurones in the adult female mouse brain. J Neuroendocrinol (2009) 21:673-82. doi:10.1111/j.1365-2826.2009.01892.x

22. Rommerts FF, King SR, Span PN. Implications of progesterone metabolism in MA-10 cells for accurate measurement of the rate of steroidogenesis. Endocrinology (2001) 142:5236-42. doi:10.1210/en.142.12.5236

23. Mei H, Walters C, Carter R, Colledge WH. Gpr54-/- mice show more pronounced defects in spermatogenesis than Kiss1-/- mice and improved spermatogenesis with age when exposed to dietary phytoestrogens. Reproduction (2011) 141:357-66. doi:10.1530/REP-10-0432

24. Wahab F, Quinton R, Seminara SB. The kisspeptin signaling pathway and its role in human isolated GnRH deficiency. Mol Cell Endocrinol (2011) 346:29-36. doi:10.1016/j.mce.2011.05.043
25. Clarkson J, d'Anglemont de Tassigny X, Moreno AS, Colledge WH, Herbison AE. Kisspeptin-GPR54 signaling is essential for preovulatory gonadotropinreleasing hormone neuron activation and the luteinizing hormone surge. J Neurosci (2008) 28:8691-7. doi:10.1523/JNEUROSCI.1775-08.2008

26. Kleene KC. Patterns, mechanisms, and functions of translation regulation in mammalian spermatogenic cells. Cytogenet Genome Res (2003) 103:217-24. doi:10.1159/000076807

27. Kleene KC. Poly(A) shortening accompanies the activation of translation of five mRNAs during spermiogenesis in the mouse. Development (1989) 106:367-73.

28. Huma T, Ullah F, Hanif F, Rizak JD, Shahab M. Peripheral administration of kisspeptin antagonist does not alter basal plasma testosterone but decreases plasma adiponectin levels in adult male rhesus macaques. Eur J Sci Res (2013) 109:668-77.

29. Kirilov M, Clarkson J, Liu X, Roa J, Campos P, Porteous R, et al. Dependence of fertility on kisspeptin-Gpr54 signaling at the GnRH neuron. Nat Commun (2013) 4:2492. doi:10.1038/ncomms3492

Conflict of Interest Statement: The authors declare that the research was conducted in the absence of any commercial or financial relationships that could be construed as a potential conflict of interest.

Received: 28 November 2013; paper pending published: 11 December 2013; accepted: 13 December 2013; published online: 30 December 2013.

Citation: Mei H, Doran J, Kyle V, Yeo S-H and Colledge WH (2013) Does kisspeptin signaling have a role in the testes? Front. Endocrinol. 4:198. doi: 10.3389/fendo.2013.00198 This article was submitted to Experimental Endocrinology, a section of the journal Frontiers in Endocrinology.

Copyright (c) 2013 Mei, Doran, Kyle, Yeo and Colledge. This is an open-access article distributed under the terms of the Creative Commons Attribution License (CC BY). The use, distribution or reproduction in other forums is permitted, provided the original author(s) or licensor are credited and that the original publication in this journal is cited, in accordance with accepted academic practice. No use, distribution or reproduction is permitted which does not comply with these terms. 